\title{
Vitamin D and Vascular Smooth Muscle Cells: Gene Modulation Following Exposure to a Diabetic-Like Environment \\ Tali Zitman-Gal ${ }^{1 *}$, Janice Green ${ }^{1}$, Metsada Pasmanik-Chor ${ }^{2}$, Varda Oron-Karni' ${ }^{2}$, Jacques Bernheim ${ }^{1,3}$ and Sydney Benchetrit ${ }^{1,3}$
}

${ }^{1}$ Renal Physiology Laboratory, Department of Nephrology and Hypertension, Meir Medical Center, Kfar Saba, Israel

${ }^{2}$ Bioinformatics Unit, Tel Aviv University, Tel Aviv, Israel

${ }^{3}$ Sackler Faculty of Medicine, Tel Aviv University, Tel Aviv, Israel

\begin{abstract}
Background: Diabetes mellitus (DM) is one of the leading causes of chronic vascular disease, which can accelerate the development of cardiovascular and renal disorders. Vascular smooth muscle cells (VSMC) are involved in the occurrence of vascular atherosclerosis and arteriosclerosis. Calcitriol might inhibit endothelial proliferation, blunt angiogenesis, and serve as a cardioprotective agent. We evaluated the impact of a diabetic-like environment and calcitriol on VSMC gene and protein expression.
\end{abstract}

Methods: VSMC were treated for 24 hours using $200 \mu \mathrm{g} / \mathrm{ml}$ AGE-HSA, $250 \mathrm{mg} / \mathrm{dl}$ glucose and $10^{-9}$ or $10^{-10} \mathrm{~mol} / \mathrm{l}$ calcitriol. Microarray gene chip analysis, real time PCR, western blot and ELISA techniques were used to determine gene and protein expression.

Results: A total of 2,693 genes were differentially expressed in a diabetic-like environment compared to control, with 1796 up-regulated and 897 down-regulated. These genes are responsible for functions involved in the regulation of metabolic processes, apoptosis and cell adhesion. Addition of calcitriol at physiological concentrations $\left(10^{-10}\right.$ $\mathrm{mol} / \mathrm{l}$ ) revealed 1,157 differentially expressed genes, with 673 up-regulated and 484 down-regulated. These genes significantly enriched functions such as regulation of small GTPase and RAS protein signal transduction, cell growth and extracellular matrix part. TXNIP, OPG, RANKL, KLF4, RANK and NFKB p50/p65 mRNA and protein expressions were further investigated.

Conclusion: High throughput approach might lead to a better understanding of the pathways involved in the biological adaptation of VSMC exposed to diabetic-like conditions and eventually the possible beneficial effects of calcitriol treatment, which might delay the development of DM-related vascular complications.

Keywords: Vascular smooth muscle cells (VSMC); Diabetes; Calcitriol; Microarray; Gene expression; Protein expression

\section{Introduction}

High concentrations of advanced glycation end products (AGEs) and glucose, which are found in the blood of patients with diabetes mellitus (DM), are considered to accelerate the development of diabetic vascular complications such as abnormal growth, proliferation, migration and hypertrophy of vascular smooth muscle cells (VSMC) and endothelial cell (EC) dysfunction [1-3]. Vascular calcification is a feature of advanced atherosclerosis and results in reduced elasticity and compliance of the vessel [4]. VSMC play an integral role in the development of atherosclerotic lesions through increased migration, proliferation and secretion of matrix components, osteogenic differentiation and the associated calcification that ensues [4]. AGEs, which are produced by non-enzymatic glycation and oxidation reactions of sugars with proteins, lipids, and nucleotides, are a hallmark of DM, chronic kidney disease and aging. They are pivotal in the processes leading to the accelerated atherosclerosis observed in these patients [5,6]. Hattori et al. [7] demonstrated that glycated serum albumin (GSA) activates VSMC by stimulating NFאB, MAPKs, extracellular signal-regulated kinase and p38 MAPK activity, leading to induction of an inflammatory response, resulting in cell proliferation and migration.

It has been demonstrated that high glucose concentrations (22 and $25 \mathrm{mmol} / \mathrm{l}$ equivalent to 400 and $450 \mathrm{mg} / \mathrm{dl}$ ) activate VSMC signal transduction networks such as protein kinase $\mathrm{C}$, mitogen-activated protein kinases (MAPKs), nuclear factor kappa-light-chain-enhancer of activated B cells (NFKB), and Janus-family of activated kinases [8-11].
An increase in the expression of inducible nitric oxide synthase (iNOS) [11] is also observed and in an oxidative environment, higher production of $\mathrm{NO}$ can react with superoxide and increase peroxynitrite formation. In a previous study [12] using a high throughput microarray approach, we showed that diabetic-like conditions $(250 \mathrm{mg} / \mathrm{dl}$ glucose and AGEHSA at a concentration similar to that found in the blood of diabetic patients) induced a significantly elevated expression of endothelial inflammatory-related genes through the NFkB pathway and also stimulated the production of thioredoxin interacting protein (TXNIP). TXNIP, an inhibitor of the redox regulator thioredoxin, has multiple functions in EC, including regulating cell metabolism, growth, and inflammation [13,14]. Adding calcitriol $(1 \alpha, 25(\mathrm{OH}) \mathrm{D} 3)$, the active form of vitamin $\mathrm{D}_{3}$ to this in vitro system significantly down-regulated the inflammatory response of gene and protein expression involved in the NFkB signal transduction pathway [15]. Calcitriol, a key factor

*Corresponding author: Tali Zitman-Gal, Renal Physiology Laboratory, Department of Nephrology and Hypertension, Meir Medical Center, Kfar Saba, 44281 Israel, Tel: + 972-9-7472401; Fax: + 972-9-7416918; E-mail: tali.gal@clalit.org.il

Received August 21, 2012; Accepted October 18, 2012; Published October 24 2012

Citation: Zitman-Gal T, Green J, Pasmanik-Chor M, Oron-Karni V, Bernheim J, et al. (2012) Vitamin D and Vascular Smooth Muscle Cells: Gene Modulation Following Exposure to a Diabetic-Like Environment. J Diabetes Metab 3: 218 doi:10.4172/2155-6156.1000218

Copyright: (c) 2012 Zitman-Gal T, et al. This is an open-access article distributed under the terms of the Creative Commons Attribution License, which permits unrestricted use, distribution, and reproduction in any medium, provided the original author and source are credited. 
in regulating calcium and phosphorus homeostasis via vitamin $\mathrm{D}$ receptors, was also found to inhibit endothelial proliferation and blunt angiogenesis $[16,17]$. In addition, it serves as a renoprotective agent [18-21]. In cultured VSMC, the presence of high amounts of calcitriol $\left(10^{-7} \mathrm{~mol} / \mathrm{l}\right)$ can up-regulate the production of proteins involved with calcium deposition by depressing endogenous parathyroid hormonerelated peptide expression, leading to vascular calcification associated with up-regulation of osteoblast-associated proteins [22,23].

Following the results observed in EC regarding the general impact of DM and vitamin $\mathrm{D}$ on vasculature and the involvement of VSMC in the development of vasculopathies with calcification $[12,15]$, we used microarray technology to detect gene expression profiles in VSMC exposed to diabetic-like conditions, both with and without physiological concentrations of calcitriol. In previous studies [24,25], primary human umbilical artery SMC were used as a model for investigating the effects of high glucose on VSMC function. To the best of our knowledge, there are no previous studies dealing with the effects of mildly elevated extracellular glucose concentrations in the presence of AGEs (mimicking the cellular environment seen in patients with diabetes) and physiological calcitriol concentrations on VSMC function.

\section{Materials and Methods}

\section{Cell culture and incubation}

VSMC were isolated from human umbilical cord arteries obtained from the maternity unit at Meir Medical Center, Kfar Saba, Israel as previously described [26]. The Ethical Review Committee approved the study and the parturient was requested to provide written informed consent. In brief, umbilical cords were collected shortly after delivery; arteries were dissected, cleaned of blood and adventitia, and cut into tiny slices. The segments were kept in culture M-199 medium, supplemented with $20 \%$ FCS, $100 \mathrm{U} / \mathrm{ml}$ penicillin and $100 \mu / \mathrm{ml}$ streptomycin (Biological Industries, Bet Haemek, Israel). Cell culture purity was confirmed by positive SMC $\alpha$-actin staining. After passage 3-5, cells were treated for $24 \mathrm{~h}$ with $200 \mu \mathrm{g} / \mathrm{ml}$ human serum albumin (HSA) and $100 \mathrm{mg} / \mathrm{dl}$ glucose (control group) or $200 \mu \mathrm{g} / \mathrm{ml} \mathrm{AGE-HSA} \mathrm{[27]} \mathrm{and}$ $250 \mathrm{mg} / \mathrm{dl}$ glucose (diabetic-like environment). D-Mannitol (SigmaAldrich, St. Louis, MO, USA) (equivalent concentrations of glucose) was used as an osmotic control. Calcitriol $10^{-9}$ or $10^{-10} \mathrm{~mol} / \mathrm{l}$ (American Reagent Inc., Shirley, NY, USA) (corresponding to supraphysiological and physiological blood concentrations, respectively) $[15,28]$ was added to cells $1 \mathrm{~h}$ after stimulation for an additional $23 \mathrm{~h}$.

\section{RNA extraction and Reverse Transcription (RT) PCR}

Total RNA was extracted from VSMC using RNeasy Mini Kit, including DNase digestion with RNase-free DNase set (Qiagen, Valencia, CA, USA) according to manufacturer's instructions. RNA integrity was assessed using NanoDrop (Thermo Fisher Scientific, Inc, Wilmington, DE, USA). RNA ( $1 \mu \mathrm{g})$ was then reverse transcribed into single-strand DNA using High Capacity cDNA Reverse Transcription Kit (Applied Biosystems Inc, Foster City, CA, USA), according to the manufacturer's instructions. Total RNA from the treatment of HSA, AGE-HSA plus glucose $(250 \mathrm{mg} / \mathrm{dl})$ and calcitriol $10^{-10} \mathrm{~mol} / \mathrm{l}$ was further investigated with microarray GeneChip technology.

Microarray experiment: Affymetrix GeneChip ${ }^{\circledR}$ Human Gene 1.0 ST arrays were used for gene expression analysis according to the instruction manual, as described in URL 1 (Affymetrix, Santa Clara, CA, USA). (http://www.affymetrix.com/support/technical/datasheets/ human_datasheet.pdf). Two biological repeats were used for each treatment.

Microarray bioinformatics analysis: Microarray analysis was performed using Partek ${ }^{\circledR}$ Genomics SuiteTM (Partek GS, Partek Inc., MO, USA). Quantile normalization was performed by the robust multi-average method (RMA). Batch effect removal was applied for the different samples to remove individual variations, followed by one-way analysis of variance (ANOVA). Genes of interest that were differentially expressed ( $\mathrm{p}<0.05$; fold-change cutoff 1.25 ) were obtained. The David and WebGestalt databases (http://david.abcc. ncifcrf.gov and http://bioinfo.vanderbilt.edu/webgestalt, respectively) were used for functional annotations of gene lists.

Real-Time PCR: Selected genes that were found to be up-regulated, down-regulated or unchanged in the microarray analysis were chosen to be validated by real time PCR using mRNA samples from 3 additional biological repeats (total of 5 repeats). Real time PCR was also performed on a calcitriol concentration of $10^{-9} \mathrm{~mol} / \mathrm{l}$ to compare the effects of supraphysiological $\left(10^{-9} \mathrm{~mol} / \mathrm{l}\right)$ and physiological concentrations $\left(10^{-10} \mathrm{~mol} / \mathrm{l}\right)$ of calcitriol. TaqMan real-time PCR amplification was used with gene specific primer for tumor necrosis factor (ligand) superfamily (TNFSF11, also known as receptor activator of nuclear factor- $\kappa B$ ligand (RANKL), tumor necrosis factor receptor superfamily member 11B (TNFRSF11B, also known as osteoprotegerin (OPG) and Kruppel-like factor (KLF) 4 (Applied Biosystems Inc, Foster City, CA, USA), using hypoxanthine phosphoribosyltransferase 1 (HPRT1) and glucuronidase, beta (GUSB) as control genes. For TXNIP mRNA validation, we used Syber Green I reaction mix (Applied Biosystems Inc, Foster City, CA, USA). GUSB and HPRT1 were used as a reference gene. Data were analyzed using the $2^{-\Delta \Delta C t}$ method. Individual primers were used as described below:

TXNIP primers: forward primer 5'-AGATCAGGTCTAAGCAGCAGAACA-3'; reverse primer 5' - CCATATAGCAGGGAGGAGCTTC-3'

GUSB primers: forward primer 5'-CAATACCTGACTGACACCTCCAGTA-3'; reverse primer 5'- TGGTGGGTGTCGTGTACAGAAGT-3'

HPRT1 primers: forward primer 5' - CCTCATGGACTAATTATGGACAGGA-3'; reverse primer 5'- GCACACAGAGGGCTACAATGTG-3'.

Western blot: Protein expressions of TXNIP, RANK, KLF4, NFkB p50/p65 and $\alpha$-tubulin, were studied by a standard western blot technique as described previously [13], using monoclonal antibodies against TXNIP (1:1000; MBL International, Woburn, MA, USA), RANK (1:1000; Cell Signaling Technology Danvers, MA, USA), KLF4 (1:1000; Cell Signaling Technology Danvers, MA,USA), NFkB p65 (1:4500; Lab Vision, Fremont, CA, USA), NFkB p50 (1:500; Santa Cruz, CA, USA) and $\alpha$-tubulin (1:10,000; Sigma-Aldrich, St. Louis, MO, USA) as the loading control. The second antibody was goat antirabbit IgG with horseradish peroxidase (Jackson ImmunoResearch Laboratories, West Grove, PA, USA) for RANKL, KLF4 and NFkB p65. Sheep anti-mouse IgG with horseradish peroxidase (Jackson ImmunoResearch Laboratories, West Grove, PA, USA) was used for NFkB p50, TXNIP and $\alpha$-tubulin. The nitrocellulose membranes were stripped and reprobed with the above antibodies. The bound antibodies were visualized with the enhanced chemiluminescent reporter system (ECL, Santa Cruz, CA, USA). LAS-3500 (Fuji, Japan) was used for quantification. Quantification of the protein expressions were normalized against the quantification of $\alpha$-tubulin expression.

ELISA: RANKL and OPG levels were determined in culture media supernatants from control cells and from cells exposed to a diabeticlike environment and calcitriol, according to the manufacturer's 
Citation: Zitman-Gal T, Green J, Pasmanik-Chor M, Oron-Karni V, Bernheim J, et al. (2012) Vitamin D and Vascular Smooth Muscle Cells: Gene Modulation Following Exposure to a Diabetic-Like Environment. J Diabetes Metab 3: 218. doi:10.4172/2155-6156.1000218

Page 3 of 9

instructions (Biomedica, Vienna, Austria and R and D Systems, Inc. Minneapolis, MN, USA).

\section{Statistical analysis}

All data are expressed as mean \pm SD (standard deviation). One way ANOVA, Kruskal-Wallis Test and Student's paired $t$-test were used for data analysis of real time PCR and western blot. P values of 0.05 or less were considered significant.

\section{Results}

\section{Microarray analysis}

Gene expression in cultured VSMC exposed to a diabetic-like environment revealed 2,693 annotated genes that were significantly changed ( $\mathrm{p}<0.05$, fold change cut-off 1.25 ) when compared to control cells. Of these, 1,796 genes $(66 \%)$ were up-regulated, with functional annotations as cellular metabolic processes, cell death, mitotic cell cycle (Figure 1A) as well as cellular catabolic processes (KLF4, KLF10, KLF11,
TXNIP), cytokine receptor interaction (CCL3) or apoptosis (BCL10, BTG1) (Table 1). A total of 897 genes (34\%) were down-regulated with enriched functions such as biological and cell adhesion (EGF1, BMP1, ICAM1), receptor protein signaling pathway (PDGFRB, TGFB1I1, SMAD3), and osteoclast differentiation (RANKL) (Figure 1A; Table 1).

A total of 1,157 annotated genes were affected by calcitriol treatment $\left(10^{-10} \mathrm{~mol} / \mathrm{l}\right)$ to cells in the diabetic-like environment ( $p<0.05$ and fold-change cut-off 1.25). Of these, 673 genes $(58 \%)$ were up-regulated, corresponding to functions such as regulation of small GTPase mediated signal transduction, regulation of Ras protein signal transduction (Figure 1B) as well as biological and cell adhesion (BMP1, ICAM), extracellular matrix part (COL4A2), and osteoclast differentiation (OPG) (Table 1). The remaining 484 genes (42\%) were down-regulated, corresponding to functions such as negative regulation of cell growth, cellular carbohydrate catabolic process (Figure 1B), as well as apoptosis (BCL10, BTG1), cellular metabolic process (KLF4, CYP51A1), and oxidoreductase activity (TXNDC17) (Table 1).
A
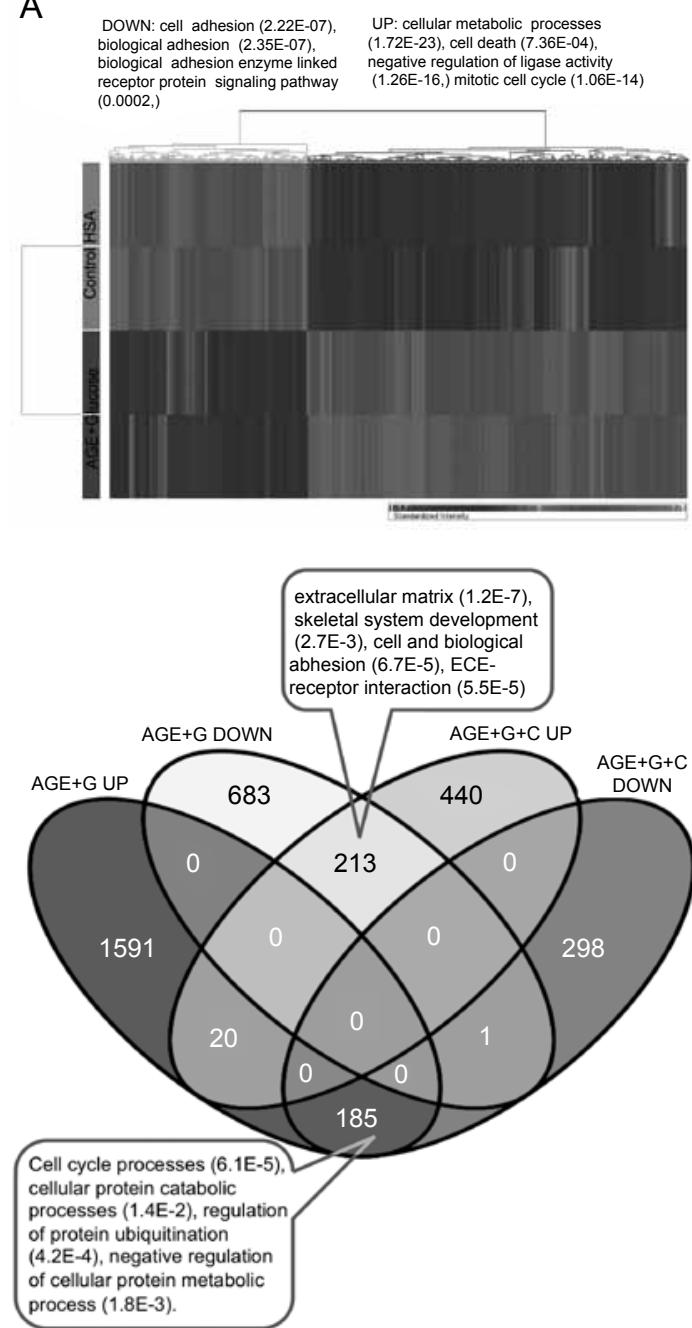

B

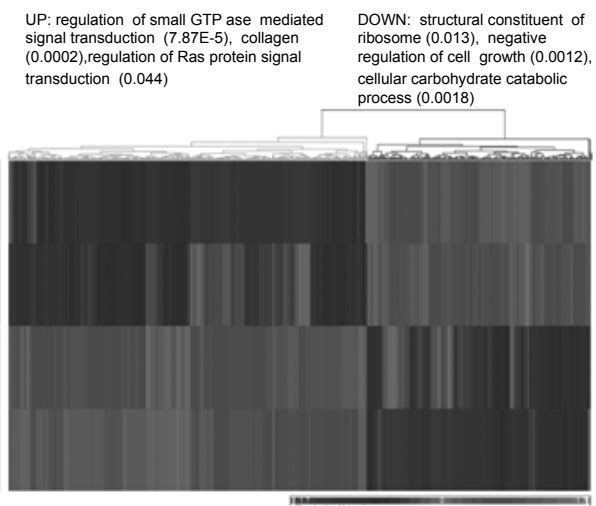

Figure 1: Cluster analysis on microarray data. Hierarchical clustering was performed on differentially expressed genes for the following treatments: (A) diabeticlike environment $\left(200 \mu \mathrm{g} / \mathrm{ml}\right.$ AGE-HSA and $250 \mathrm{mg} / \mathrm{dl}$ glucose) vs. control (100 $\mu \mathrm{g} / \mathrm{ml} \mathrm{HSA}$ and $100 \mathrm{mg} / \mathrm{dl}$ glucose), (B) Diabetic environment and $10^{-10} \mathrm{~mol} / \mathrm{l} \mathrm{calcitriol}$ treatment vs. diabetic environment only $(200 \mu \mathrm{g} / \mathrm{ml} \mathrm{AGE-HSA}$ and $250 \mathrm{mg} / \mathrm{dl}$ glucose). Enriched biological pathways represented by the differentially expressed genes are suggested. (C) Venn diagram representing common and unique differentially expressed genes regulated by a diabetic-like environment (AGE+G) and diabetic-like environment plus $10^{-10} \mathrm{~mol} / \mathrm{l}$ calcitriol $(\mathrm{AGE}+\mathrm{G}+\mathrm{C})$. 
Citation: Zitman-Gal T, Green J, Pasmanik-Chor M, Oron-Karni V, Bernheim J, et al. (2012) Vitamin D and Vascular Smooth Muscle Cells: Gene Modulation Following Exposure to a Diabetic-Like Environment. J Diabetes Metab 3: 218. doi:10.4172/2155-6156.1000218

Page 4 of 9

\begin{tabular}{|c|c|c|c|c|c|}
\hline $\begin{array}{l}\text { Accession } \\
\text { number (NCBI) }\end{array}$ & Gene description & Gene Symbol & $\begin{array}{l}\text { Enriched functional and pathway annotations } \\
\text { (David and Webgestalt) }\end{array}$ & $\begin{array}{l}\text { Diabetic environment } \\
\text { (Fold change, } p<0.05 \text { ) }\end{array}$ & $\begin{array}{l}\text { Diabetic environment and } \\
\text { calcitriol (Fold change } p<0.05 \text { ) }\end{array}$ \\
\hline NM_004235 & Kruppel-like factor 4 & KLF4 & $\begin{array}{l}\text { Cellular metabolic process, ubiquitin-dependent } \\
\text { protein catabolic process, intracellular organelle } \\
\text { part, transcription repressor activity }\end{array}$ & +1.48 & -1.28 \\
\hline NM_000786 & $\begin{array}{l}\text { Cytochrome P450, } \\
\text { family } 51 \text {, subfamily A }\end{array}$ & CYP51A1 & $\begin{array}{l}\text { Cellular metabolic process, cytoplasmic and } \\
\text { organelle part, metabolic process, steroid } \\
\text { biosynthesis, metabolic processes }\end{array}$ & +1.44 & -1.72 \\
\hline NM_002983 & $\begin{array}{l}\text { Chemokine }(\mathrm{C}-\mathrm{C} \\
\text { motif) ligand } 3\end{array}$ & CCL3 & $\begin{array}{l}\text { Chemokine signaling pathway, Toll-like receptor } \\
\text { signaling pathway, Cytokine-cytokine receptor } \\
\text { interaction }\end{array}$ & +1.48 & -1.37 \\
\hline NM_004064 & $\begin{array}{l}\text { Cyclin-dependent } \\
\text { kinase inhibitor 1B }\end{array}$ & CDKN1B & $\begin{array}{l}\text { cellular metabolic process, cell cycle process, } \\
\text { regulation of cell proliferation, pathways in } \\
\text { cancer, }\end{array}$ & +1.26 & -1.48 \\
\hline NM_032731 & $\begin{array}{l}\text { Thioredoxin domain } \\
\text { containing } 17\end{array}$ & TXNDC17 & $\begin{array}{l}\text { Oxidoreductase activity, intracellular part, } \\
\text { cytoplasm, nitrogen compound metabolic } \\
\text { process, protein binding }\end{array}$ & +1.39 & -1.26 \\
\hline NM_003921 & $\begin{array}{l}\text { B-cell CLL/lymphoma } \\
10\end{array}$ & BCL10 & $\begin{array}{l}\text { Apoptosis, cellular process, negative regulation } \\
\text { of cell growth, positive regulation of biological } \\
\text { process }\end{array}$ & +1.46 & -1.33 \\
\hline NM_001731 & $\begin{array}{l}\text { B-cell translocation } \\
\text { gene } 1 \text {, anti- } \\
\text { proliferative }\end{array}$ & BTG1 & $\begin{array}{l}\text { Endothelial cell differentiation, endothelium } \\
\text { development, negative regulation of cell growth, } \\
\text { transcription regulator activity }\end{array}$ & +1.59 & -1.39 \\
\hline NM_002609 & $\begin{array}{l}\text { Platelet-derived } \\
\text { growth factor } \\
\text { receptor, beta } \\
\text { polypeptide }\end{array}$ & PDGFRB & $\begin{array}{l}\text { Multicellular organismal development, enzyme } \\
\text { linked receptor protein signaling pathway, } \\
\text { system development, regulation of protein } \\
\text { modification process, cell motion }\end{array}$ & -1.65 & +1.35 \\
\hline NM_005902 & $\begin{array}{l}\text { SMAD family member } \\
3\end{array}$ & SMAD3 & $\begin{array}{l}\text { Transcriptional modulator activated by TGF-beta } \\
\text { (transforming growth factor) and activin type } 1 \\
\text { receptor kinase. SMAD3 is a receptor-regulated } \\
\text { SMAD (R-SMAD) }\end{array}$ & -1.24 & $+1.2(p=0.08)$ \\
\hline NM_005228 & $\begin{array}{l}\text { Epidermal growth } \\
\text { factor receptor }\end{array}$ & EGFR & $\begin{array}{l}\text { Biological adhesion, multicellular organismal } \\
\text { development, developmental process, positive } \\
\text { regulation of molecular, cellular and biological } \\
\text { process, cell cycle process }\end{array}$ & -1.39 & +1.4 \\
\hline NM_006129 & $\begin{array}{l}\text { Bone morphogenetic } \\
\text { protein } 1\end{array}$ & BMP1 & $\begin{array}{l}\text { Cell and biological adhesion, skeletal system } \\
\text { development, metabolism of lipids and } \\
\text { lipoproteins, calcium ion binding }\end{array}$ & -1.26 & +1.32 \\
\hline NM_001846 & $\begin{array}{l}\text { Collagen, type IV, } \\
\text { alpha } 2\end{array}$ & COL4A2 & $\begin{array}{l}\text { Extracellular matrix part, ECM-receptor } \\
\text { interaction, collagen, multicellular organismal } \\
\text { development, anatomical structure } \\
\text { morphogenesis }\end{array}$ & -1.59 & +1.32 \\
\hline NM_000201 & $\begin{array}{l}\text { Intercellular adhesion } \\
\text { molecule } 1\end{array}$ & ICAM1 & $\begin{array}{l}\text { Cell and biological adhesion, positive regulation } \\
\text { of molecular, cellular and biological process, cell } \\
\text { motion }\end{array}$ & -1.27 & +1.33 \\
\hline NM_006472 & $\begin{array}{l}\text { Thioredoxin } \\
\text { interacting protein }\end{array}$ & TXNIP & $\begin{array}{l}\text { Cellular metabolic process, intracellular } \\
\text { organelle part, cellular biosynthetic process, } \\
\text { regulation of metabolic process }\end{array}$ & +10.02 & $-1.4(p=0.6)$ \\
\hline NM_005655 & Kruppel-like factor 10 & KLF10 & $\begin{array}{l}\text { Cellular metabolic process, mitotic cell cycle, } \\
\text { nitrogen compound metabolic process, negative } \\
\text { regulation of macromolecule metabolic process, } \\
\text { negative regulation of cellular metabolic process }\end{array}$ & +1.65 & $-1.8(p=0.2)$ \\
\hline NM_003597 & Kruppel-like factor 11 & KLF11 & $\begin{array}{l}\text { Cellular metabolic process, negative regulation } \\
\text { of macromolecule metabolic process, negative } \\
\text { regulation of cellular metabolic process }\end{array}$ & +1.69 & $-1.2(p=0.39)$ \\
\hline NM_001042454 & $\begin{array}{l}\text { Transforming growth } \\
\text { factor beta } 1 \text { induced }\end{array}$ & TGFB1I1 & $\begin{array}{l}\text { Focal adhesion, enzyme linked receptor protein } \\
\text { signaling pathway, protein kinase activity, } \\
\text { multicellular organismal development }\end{array}$ & -1.41 & $+1.09(p=0.54)$ \\
\hline NM_003701 & $\begin{array}{l}\text { Tumor necrosis factor } \\
\text { (ligand superfamily) }\end{array}$ & $\begin{array}{l}\text { TNFSF11 } \\
\text { RANKL }\end{array}$ & $\begin{array}{l}\text { Cytokine-cytokine receptor interaction, } \\
\text { osteoclast differentiation rheumatoid arthritis }\end{array}$ & -1.21 & $-1.02(p=0.7)$ \\
\hline NM_002546 & $\begin{array}{l}\text { Tumor necrosis factor } \\
\text { receptor superfamily }\end{array}$ & $\begin{array}{l}\text { TNFRSF11B } \\
\text { OPG }\end{array}$ & $\begin{array}{l}\text { Cytokine-cytokine receptor interaction, } \\
\text { osteoclast differentiation }\end{array}$ & $+1.11(p=0.26)$ & $+1.19(p=0.07)$ \\
\hline
\end{tabular}

Table 1: Genes differentially regulated by a diabetic environment $(200 \mu \mathrm{g} / \mathrm{ml} \mathrm{AGE-HSA}$ and $250 \mathrm{mg} / \mathrm{dl}$ glucose $)$ and $10^{-10} \mathrm{~mol} / \mathrm{l} \mathrm{calcitriol}$.

When comparing the differentially expressed gene lists mentioned above, 419 genes were shared in a diabetic-like environment and calcitriol treatment (Figure 1C). One hundred eighty-five genes were up-regulated in a diabetic-like environment and down-regulated after calcitriol treatment, corresponding to functions such as cell cycle processes, cellular protein catabolic processes, and regulation of protein ubiquitination (Figure 1C). Two hundred thirteen genes were down-regulated following exposure to a diabetic-like environment and up-regulated following calcitriol treatments, corresponding to functions such as extracellular matrix, skeletal system development, cell and biological adhesion (Figure 1C). The Venn diagram presents the unique gene expression patterns for each treatment. From the gene 
list presented in table 1 and in the corresponding Venn diagram (Figure $1 \mathrm{C})$, we chose several interesting genes that focus on the inflammatory pathways for further validation and investigation.

\section{Validation of gene microarray results by real time RT-PCR}

To validate the gene expression changes detected by the microarray analyses, real time RT-PCR was performed on selected differentially expressed genes. This gene set included KLF4, OPG, RANKL and TXNIP (Figures 2A-2C). The expression pattern of these selected genes was also examined in a set of experiments using a supraphysiological calcitriol concentration of $10^{-9} \mathrm{~mol} / \mathrm{l}$ (Figure 2).

The expression patterns determined by real time PCR analysis confirmed those identified by the microarray analysis, including KLF4, OPG and TXNIP (Table 1). RANKL mRNA expression was modified in the real time PCR. RANKL levels were significantly elevated following exposure to diabetic conditions $(2.06 \pm 0.581, \mathrm{p}=0.016)$. The addition of calcitriol $10^{-10} \mathrm{~mol} / \mathrm{l}$ to the stimulated cells down-regulated
A

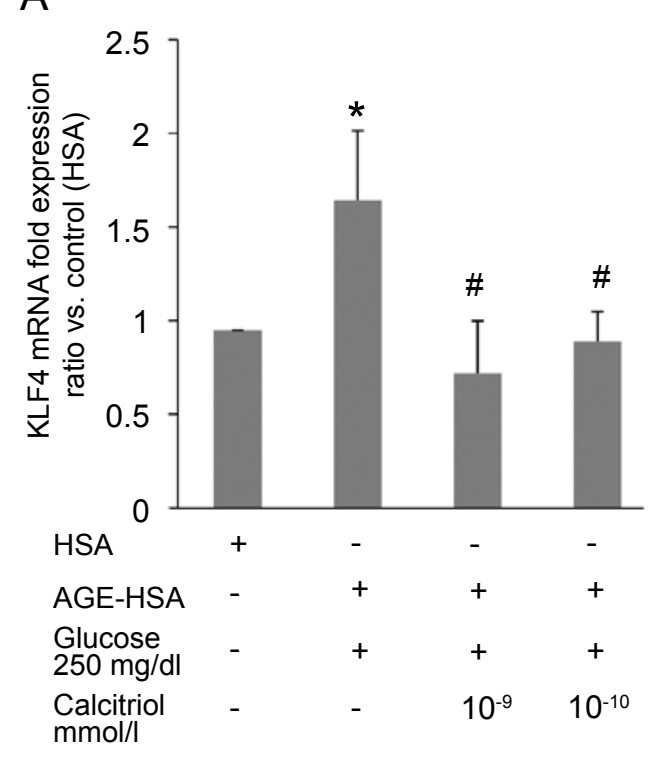

C

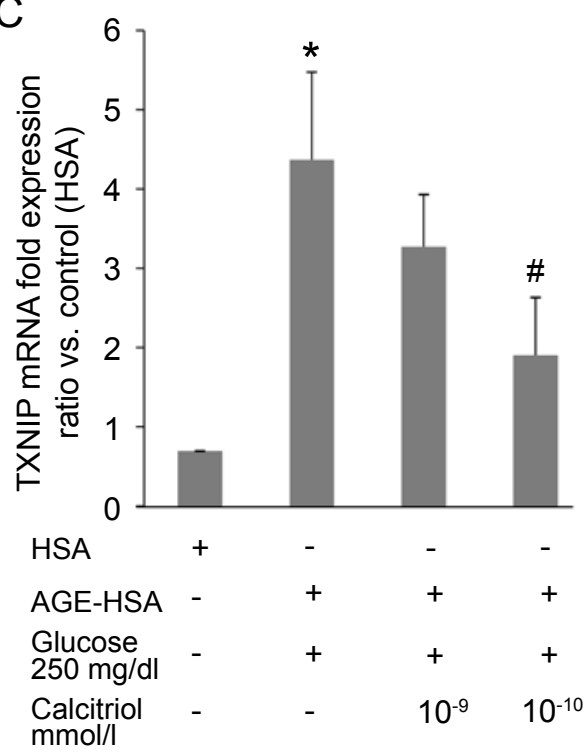

$\mathrm{B}$

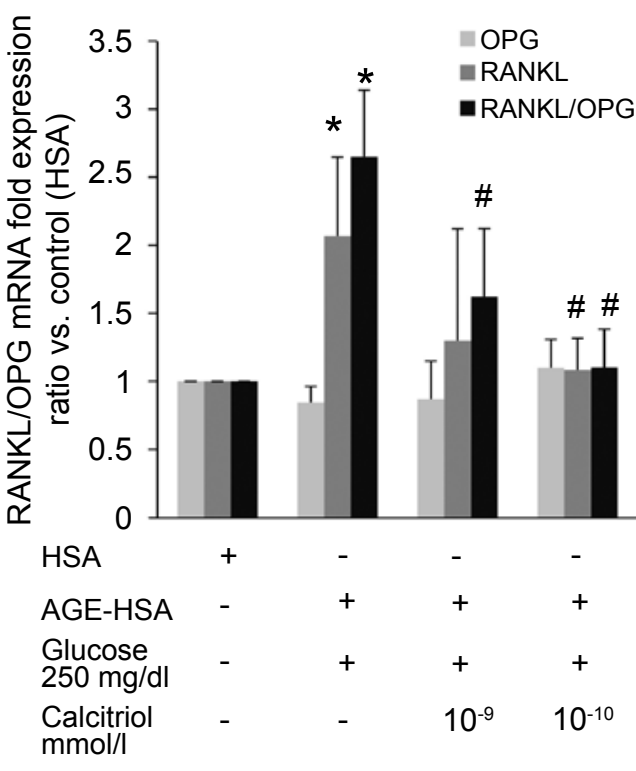

Figure 2: Effect of calcitriol on KLF4, TXNIP, OPG and RANKL mRNA expression in VSMC stimulated with diabetic environment. VSMC were incubated for $24 \mathrm{~h}$ with HSA $(200 \mu \mathrm{g} / \mathrm{ml})$, AGE-HSA $(200 \mu \mathrm{g} / \mathrm{ml})$ and glucose $(250 \mathrm{mg} / \mathrm{dl})$. In addition, $10^{-9} \mathrm{~mol} / \mathrm{l}$ and $10^{-10} \mathrm{~mol} / / \mathrm{l}$ calcitriol were given to the cells $1 \mathrm{~h}$ after stimulation for an additional $23 \mathrm{~h}$. (A) KLF4, (B) OPG, and RANKL (C) TXNIP mRNA expression were analyzed by real-time PCR and normalized to the GUSB and HPRT1. For each gene, an inset with a dot plot figure reflects the microarray gene chip results. Data are expressed as mean $\pm S D$ of $4-5$ independent experiments. ${ }^{*}<0$. 05 compared to control group-HSA; " $\mathrm{p}<0.05$ compared with AGE-Glucose. 
Citation: Zitman-Gal T, Green J, Pasmanik-Chor M, Oron-Karni V, Bernheim J, et al. (2012) Vitamin D and Vascular Smooth Muscle Cells: Gene Modulation Following Exposure to a Diabetic-Like Environment. J Diabetes Metab 3: 218. doi:10.4172/2155-6156.1000218

Page 6 of 9

RANKL mRNA expression $(1.082 \pm 0.235, \mathrm{p}=0.05)$ (not seen in the microarray analysis). The RANKL/OPG mRNA ratio was significantly elevated after exposure to a diabetic-like environment $(2.65 \pm 0.491$, $\mathrm{p}=0.00001)$, while the addition of calcitriol $\left(10^{-9}\right.$ and $\left.10^{-10} \mathrm{~mol} / \mathrm{l}\right)$ significantly down-regulated the RANKL/OPG mRNA ratio $(1.622$ \pm 0.501 and $1.102 \pm 0.282$, respectively, $\mathrm{p}=0.00001)$. TXNIP mRNA expression was significantly elevated under diabetic conditions $(4.36 \pm$ $1.01, \mathrm{p}=0.004)$, and was decreased (not seen in the microarray analysis) after the addition of $10^{-10} \mathrm{~mol} / \mathrm{l}$ calcitriol $(1.9 \pm 0.7, \mathrm{p}=0.03)$.

The majority of microarray data were consistent with the real time PCR validation, with the exception of RANKL and TXNIP expressions. This was probably due to the low number of biological repeats in the microarray analysis. Since the other validations of genes in the realtime PCR were consistent with the microarray results we continued to analyze the real time PCR results as the accurate ones.

\section{RANK, KLF4, NFkB p65/p50 and TXNIP protein expression}

To further study the effects of a diabetic-like environment and calcitriol on the inflammatory response, we examined the protein levels of RANK, KLF4, NFkB p50/p65 and TXNIP using western blot analysis. Results demonstrated that the protein levels of NFkB p50/p65, RANK, KLF4 and TXNIP were significantly increased upon exposure to a diabetic-like environment compared to the control (HSA) (fold change: NFkB p65: $1.75 \pm 0.6, p=0.04 ; \mathrm{NF \kappa B}$ p50: $1.46 \pm 0.4, \mathrm{p}=0.05$; RANK: $1.79 \pm 0.04, \mathrm{p}=0.008$, KLF4: $2.78 \pm 0.7, \mathrm{p}=0.048$; TXNIP: $1.57 \pm 0.24, \mathrm{p}=0.04$ vs. control) (Figures $3 \mathrm{~A}-3 \mathrm{C}$ ). The addition of physiological concentrations of calcitriol $\left(10^{-10} \mathrm{~mol} / \mathrm{l}\right)$ to the stimulated cells significantly decreased the expression of all proteins (fold change: RANK: $0.59 \pm 0.36, p=0.017$; TXNIP: $0.79 \pm 0.18, p=0.004$; NFKB p50: $0.66 \pm 0.22, \mathrm{p}=0.02 ; \mathrm{NF \kappa B}$ p65: $0.66 \pm 0.32, \mathrm{p}=0.04 ;$ and KLF4: $0.66 \pm$ $0.14, \mathrm{p}=0.002$. vs. diabetic environment). We also tested the protein

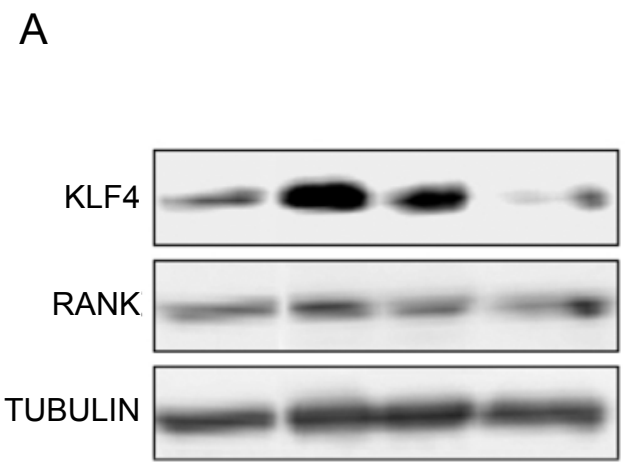

$\mathrm{B}$
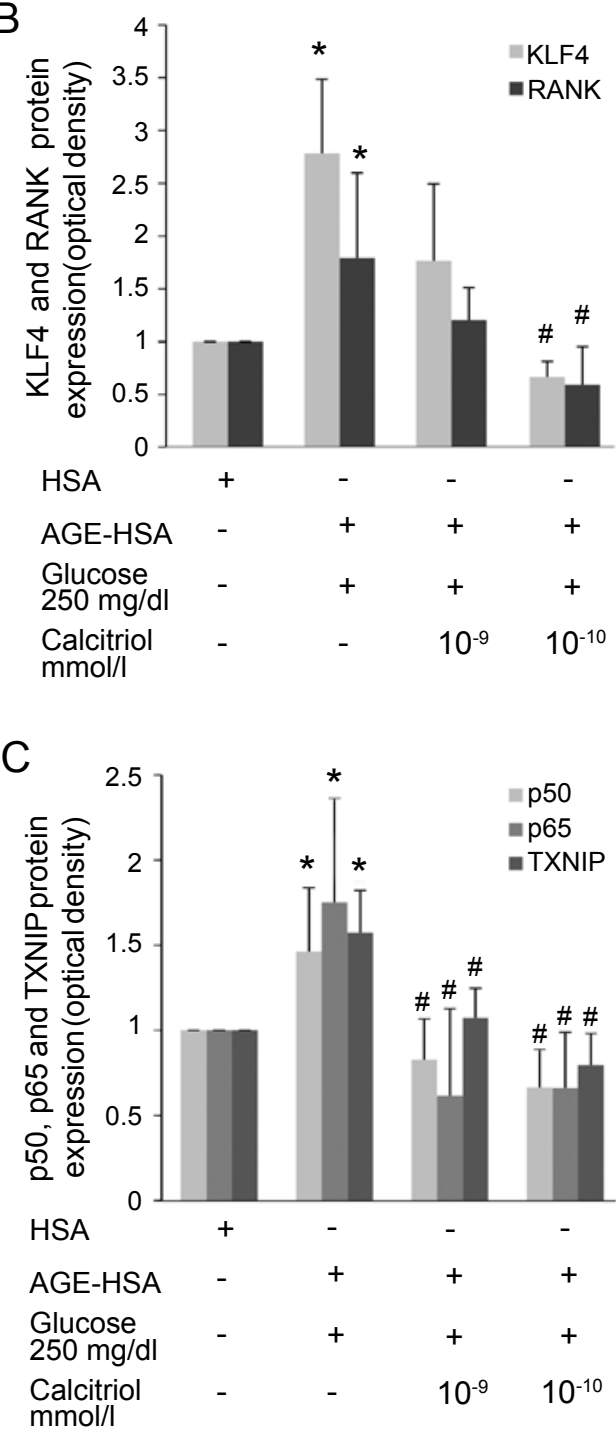

Figure 3: Effect of calcitriol on KLF4, RANK, TXNIP NFKB (p50/p65) protein expression in VSMC stimulated with diabetic environment. Western blots (A) and their densitometric analysis (B,C) of KLF4, RANK, NFKB (p50/p65), and TXNIP measured in VSMC after incubation for $24 \mathrm{~h}$ with HSA (200 $\mu \mathrm{g} / \mathrm{ml})$, AGE-HSA $(200 \mu \mathrm{g} / \mathrm{ml})$, glucose $(250 \mathrm{mg} / \mathrm{dl})$ and calcitriol $\left(10^{-9} \mathrm{~mol} / \mathrm{l}\right.$ and $\left.10^{-10} \mathrm{~mol} / \mathrm{l}\right)$. The membrane was stripped and reprobed with $\alpha$-tubulin which is shown as the loading control. Data are expressed as mean \pm SD of $4-5$ independent experiments. ${ }^{*} p<0.05$ compared to control group-HSA; $\#<00$. 05 compared with AGE-Glucose. 
Diabetic environment

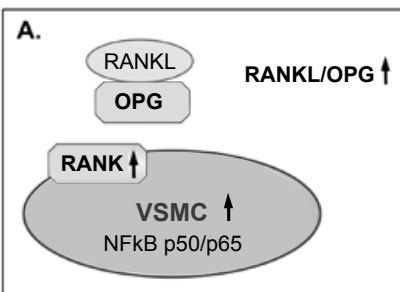

Diabetic environment and $10-{ }^{10} \mathrm{~mol} / \mathrm{l}$ calcitriol

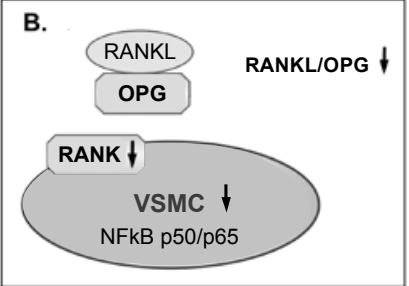

Figure 4: RANKL/OPG/RANK-NFKB pathway following stimulation of diabetic environment and calcitriol $\left(10^{-10} \mathrm{~mol} / \mathrm{l}\right)$. (A) In a diabetic environment RANKL/OPG ratio is high, RANKL binds to its receptors (RANK) on VSMCs to activate NFKB (p50/p65). (B) The addition of calcitriol $\left(10^{-10} \mathrm{~mol} / \mathrm{l}\right)$ to the stimulated cells caused downregulation of the RANKL/ OPG ratio and RANK expression followed by a decrease of NFKB (p50/p65).

expression with supra-physiological concentrations of calcitriol $\left(10^{-9}\right.$ $\mathrm{mol} / \mathrm{l})$ vs. cells stimulated by a diabetic-like environment and observed significant decreases in TXNIP $(1.07 \pm 0.17, \mathrm{p}=0.014)$, NFkB p50 $(0.82$ $\pm 0.23 \mathrm{p}=0.02)$ and $\mathrm{NF \kappa B}$ p65 $(0.62 \pm 0.5, \mathrm{p}=0.02)$ (Figures $3 \mathrm{~A}-3 \mathrm{C}$ ). Figures $4 \mathrm{~A}$ and $4 \mathrm{~B}$ summarize the modifications of RANKL/OPG/ RANK and NFKB upon the different stimuli.

RANK and KLF4 decreased, but not significantly. Despite the nonsignificant decrease following supra-physiological concentrations of calcitriol, the trend is similar to that observed following physiological concentrations. One of the possible reasons could be the therapeutic window of the calcitriol which is affected differently in supraphysiological conditions.

VSMC that were treated with D-Mannitol for 24 hours did not show induction of the proteins (data not shown).

\section{RANKL and OPG protein secretion}

To determine whether a diabetic-like environment with or without calcitriol triggered the activation of OPG and RANKL proteins, we measured the expression of these proteins in the supernatants that had been collected from the experiments. There were no significant changes in OPG and RANKL protein secretion following exposure to a diabetic-like environment with or without calcitriol (data not shown).

\section{Discussion}

In this study, we used high-throughput microarray technology on VSMC as a primary method of detecting differential gene expression and various annotated pathways involved in the inflammatory state that exists in a diabetic-like environment. We also compared the differential gene expression after the addition of physiological or supraphysiological concentrations of calcitriol. The same approach using microarray technology was used previously by our laboratory to detect differentially expressed genes in EC after exposure to a diabetic-like environment [12]. We showed that mildly elevated glucose concentrations (250 $\mathrm{mg} / \mathrm{dl}$ ) and AGEs activated endothelial inflammatory processes [12], while adding physiological concentrations of calcitriol $\left(10^{-10} \mathrm{~mol} / \mathrm{l}\right)$ to cultured EC had a beneficial effect on the endothelial expression of pro-inflammatory parameters, probably through the NFKB signal transduction pathway [15].

The current research demonstrated that exposing VSMC to a diabetic-like environment stimulates a long panel of genes that are involved in cellular and metabolic processes, cellular and biological adhesion, skeletal system development, and apoptosis. The changes in gene expressions in the VSMC culture stimulated with high glucose concentrations, could be considered the result of the glucose and not increased osmolarity of the milieu, as has been established in this study, as well as in other publications $[29,30]$. The addition of physiological concentrations of calcitriol to the stimulated cells had a beneficial effect on most of the differentially expressed genes. We found 419 shared genes of which 185 were up-regulated in the diabetic-like environment, were related to cellular catabolic processes and apoptosis and downregulated after stimulation with calcitriol. Two hundred thirteen genes down-regulated in the diabetic-like environment were related to cell and biological adhesion, skeletal system, positive regulation of molecular, cellular and biological process; they were up regulated after stimulation with calcitriol. Unique, expressed genes for both treatments were demonstrated and might be considered for further investigation.

The microarray observations were generally consistent with the results of real time PCR studies or protein expression that examined the selected genes RANKL, OPG, KLF4, and TXNIP that were altered following stimulation by calcitriol.

RANKL exists in two biologically active soluble forms. In one form, it is secreted by T cells, endothelial cells, or osteoblasts; and in the other, it is proteolytically cleaved from cell surfaces [31,32]. RANKL binds to its target receptor RANK on the surface of VSMC and generates multiple intracellular signals that regulate cell differentiation, function, and survival through activation of the NFKB signal transduction pathway [33]. Tseng et al. [34] established that SMC induce the expression of RANKL after stimulation with protein kinase A, which stimulates vascular calcification. OPG is a decoy receptor of RANKL, which inhibits osteoclast formation by competing with RANK $[31,32]$. OPG is produced by endothelial and smooth muscle cells in vitro and acts as a survival factor for endothelial cells [32]. The ratio RANKL/ OPG is critical to osteoclastic bone resorption. Ndip et al. recently reported that abnormal RANKL/RANK/OPG signaling was observed in vivo in diabetic patients with medial arterial calcification or Charcot neuroarthropathy [35].

In this study, the expression patterns of OPG, RANKL, and RANK were tested at the level of cellular mRNA and cell protein expression, as well as at OPG and RANKL protein secretion levels. We found that RANKL and the ratio RANKL/OPG mRNA, as well as RANK protein expression were elevated following exposure to a diabetic-like environment, while calcitriol down-regulated RANKL/OPG mRNA and RANK expression. Investigation of the expression pattern of the $\mathrm{NF} \kappa \mathrm{B}$ signal pathway revealed that $\mathrm{NF} \kappa \mathrm{B} \mathrm{p} 65 / \mathrm{p} 50$ was significantly upregulated when exposed to a diabetic-like environment. The addition of calcitriol to the stimulated cells down-regulated expression of both these proteins significantly. No RANKL or OPG protein secretion was noted. Based on these findings, we might assume that VSMC in a diabetic-like environment activates RANKL at the cellular level only. When the RANKL/OPG ratio is high, RANKL binds to its receptor (RANK), to activate the NFKB signal transduction pathway, resulting in an increased inflammatory response. The addition of calcitriol caused a decrease in the RANKL/OPG mRNA expression ratio and in RANK expression, as well as in NFkB p50/p65 protein expression, an outcome that might improve the inflammatory response.

The microarray results showed that three members from the Kruppel-like factor (KLF) family (KLF4, KLF10, KLF11) were upregulated following exposure to a diabetic-like environment. Only KLF4 was significantly down-regulated after the addition of calcitriol, while KLF10 and KLF11 were down-regulated, but not significantly. 
The KLF family is a sub-class of the zinc finger family of transcriptional regulators in cell growth and differentiation, inflammation and metabolism [36,37]. KLF4 is known to be involved in many cellular processes, cell growth, differentiation, proliferation and apoptosis [3842]. In macrophages, KLF4 has an important pro-inflammatory role. It regulates signaling pathways that control macrophage regulation through activation of NFKB p65, which induces iNOS promoter [38]. Conversely, KLF4 inhibits the expression and function of TGF- $\beta$ and SMAD3 function, resulting in inhibition of anti-inflammatory gene expression [38]. In EC, KLF4 exerts a protective anti-inflammatory effect by inhibition of $\mathrm{NFKB}$ p65, resulting in inhibited secretion of cytokines such as IL6 and IL8 [40]. In VSMC, over-expression of KLF4 is associated with growth arrest, reduced cell cycle progression and regulation of potent growth factors, such as platelet-derived growth factor receptor (PDGFRB) and transforming growth factor beta 1 induced (TGF $\beta 1$ ) [41,42]. Our microarray results showed that a diabetic-like environment stimulated KLF4 expression in VSMC, while the expression of PDGFRB, TGF $\beta 1$ and SMAD3 were down-regulated, a situation that probably caused changes in cell differentiation and proliferation. NFkB p50/p65 protein expressions were significantly up-regulated following exposure to a diabetic-like environment, a condition that might strengthen KLF4 activation on the NFKB pathway. Yet, the significance of high expression of KLF4 in VSMC exposed to a diabetic-like environment as a proinflammatory mediator needs to be further investigated. When physiological concentrations of calcitriol were added to the stimulated VSMC, KLF4, PDGFRB and SMAD3 expression $(\mathrm{p}=0.08)$ demonstrated the opposite changes. NFKB p50/ p65 expression was also down-regulated. Further analysis is needed to determine the beneficial effect of calcitriol as an anti-inflammatory agent on the physiological and pathological roles of KLF4 in VSMC.

TXNIP, which is stimulated by hyperglycemia, is considered to have a deleterious effect on the cardiovascular system due to its proapoptotic effect in suppressing thioredoxin activity [14]. It has been well demonstrated that it promotes oxidative stress and apoptosis in several types of cells, such as endothelial and smooth muscle cells [12,13], islet cells [43], and mesangial cells [44]. We previously showed that in cultured EC, TXNIP mRNA and protein expression were up-regulated following exposure to a diabetic-like environment, while no significant changes were observed after the addition of supraphysiological and physiological concentrations of calcitriol to the stimulated cells $[12,15]$. In this study, we found that TXNIP expression was up-regulated at both mRNA and protein levels in VSMC exposed to a diabetic-like environment as we found with EC. In addition, a positive effect of calcitriol was noted, which significantly decreased mRNA and protein expression, unlike our observations with EC [15].

The findings presented here provide additional insight regarding mechanisms that may be involved in regulating vitamin $\mathrm{D}$ levels in VSMC exposed to a diabetic-like environment. We focused on selected genes and proteins that were thought to participate in the inflammatory response in these cells after exposure to different stimuli and on the roles of vitamin $\mathrm{D}$ in the expression of biological and cellular pathways that might be involved in protecting VSMC. Additional in vivo studies should be considered to further understand the beneficial effects of vitamin $\mathrm{D}$ on a diabetic-like environment, as observed in our in vitro model.

\section{Acknowledgements}

This study was supported by the Recanati Fund (S. Benchetrit) grant and the Dr. Yechezkiel and Pearl Klayman Cathedra of Urology (J. Bernheim) from the Sackler Faculty of Medicine, Tel Aviv University. We thank the English medical editor, Faye Schreiber for help in preparing the manuscript.

\section{References}

1. Bakker W, Eringa EC, Sipkema P, van Hinsbergh VW (2009) Endothelia dysfunction and diabetes: roles of hyperglycemia, impaired insulin signaling and obesity. Cell Tissue Res 335: 165-189.

2. Madonna R, De Caterina R (2011) Cellular and molecular mechanisms of vascular injury in diabetes--Part I: Pathways of vascular disease in diabetes. Vascul Pharmacol 54: 68-74.

3. Igarashi M, Wakasaki H, Takahara N, Ishii H, Jiang ZY, et al. (1999) Glucose or diabetes activates p38 mitogen-activated protein kinase via different pathways. J Clin Invest 103: 185-195

4. Trion A, van der Laarse A (2004) Vascular smooth muscle cells and calcification in atherosclerosis. Am Heart J 147: 808-814.

5. Dugé de Bernonville T, Guyot S, Paulin JP, Gaucher M, Loufrani L, et al. (2010) Dihydrochalcones: Implication in resistance to oxidative stress and bioactivities against advanced glycation end-products and vasoconstriction. Phytochemistry 71: 443-452.

6. Puddu A, Viviani GL (2011) Advanced Glycation Endproducts and Diabetes. Beyond Vascular Complications. Endocr Metab Immune Disord Drug Targets 11: $132-140$

7. Hattori Y, Suzuki M, Hattori S, Kasai K (2002) Vascular smooth muscle cell activation by glycated albumin (Amadori adducts). Hypertension 39: 22-28.

8. Campbell M, Trimble ER (2005) Modification of PI3K- and MAPK-dependen chemotaxis in aortic vascular smooth muscle cells by protein kinase Cbetall. Circ Res 96: 197-206.

9. Campbell M, Allen WE, Silversides JA, Trimble ER (2003) Glucose-induced phosphatidylinositol 3-kinase and mitogen-activated protein kinase-dependent upregulation of the platelet-derived growth factor-beta receptor potentiates vascular smooth muscle cell chemotaxis. Diabetes 52: 519-526.

10. Inaba T, Ishibashi S, Gotoda T, Kawamura M, Morino N, et al. (1996) Enhanced expression of platelet-derived growth factor-beta receptor by high glucose. Involvement of platelet-derived growth factor in diabetic angiopathy. Diabetes 45: 507-512.

11. Lafuente N, Matesanz N, Azcutia V, Romacho T, Nevado J, et al. (2008). The deleterious effect of high concentrations of $\mathrm{D}$-glucose requires pro-inflammatory preconditioning. J Hypertens 26: 478-485.

12. Zitman-Gal T, Green J, Pasmanik-Chor M, Oron-Karni V, Bernheim J (2010) Endothelial pro-atherosclerotic response to extracellular diabetic-like environment: possible role of thioredoxin-interacting protein. Nephrol Dial Transplant 25: 2141-2149.

13. Schulze PC, Yoshioka J, Takahashi T, He Z, King GL, et al. (2004) Hyperglycemia promotes oxidative stress through inhibition of thioredoxin function by thioredoxin-interacting protein. J Biol Chem 279: 30369-30374.

14. Yamawaki H, Berk BC (2005) Thioredoxin: a multifunctional antioxidant enzyme in kidney, heart and vessels. Curr Opin Nephrol Hypertens 14: 149-153.

15. Zitman-Gal T, Golan E, Green J, Bernheim J, Benchetrit S (2012) Vitamin D receptor activation in a diabetic-like environment: potential role in the activity of the endothelial pro-inflammatory and thioredoxin pathways. J Steroid Biochem Mol Biol 132: 1-7.

16. Adams JS, Hewison M (2010) Update in Vitamin D. J Clin Endocrinol Metab 95: $471-478$

17. Teng M, Wolf M, Lowrie E, Ofsthun N, Lazarus JM, et al. (2003) Survival of patients undergoing hemodialysis with paricalcitol or calcitriol therapy. $\mathrm{N}$ Engl J Med 349: 446-456

18. Bernardi RJ, Johnson CS, Modzelewski RA, Trump DL (2002) Antiproliferative effects of 1alpha,25-dihydroxyvitamin $D(3)$ and vitamin $D$ analogs on tumorderived endothelial cells. Endocrinology 143: 2508-2514.

19. Chung I, Han G, Seshadri M, Gillard BM, Yu WD, et al. (2009) Role of vitamin D receptor in the antiproliferative effects of calcitriol in tumor-derived endothelial cells and tumor angiogenesis in vivo. Cancer Res 69: 967-975.

20. Ford ES, Ajani UA, McGuire LC, Liu S (2005) Concentrations of serum vitamin $\mathrm{D}$ and the metabolic syndrome among U.S. adults. Diabetes Care 28: 1228 1230 . 
Citation: Zitman-Gal T, Green J, Pasmanik-Chor M, Oron-Karni V, Bernheim J, et al. (2012) Vitamin D and Vascular Smooth Muscle Cells: Gene Modulation Following Exposure to a Diabetic-Like Environment. J Diabetes Metab 3: 218. doi:10.4172/2155-6156.1000218

21. Holick MF (2007) Vitamin D deficiency. N Engl J Med 357: 266-281.

22. Jono S, Nishizawa $Y$, Shioi A, Morii H (1998) 1,25-Dihydroxyvitamin D3 increases in vitro vascular calcification by modulating secretion of endogenous parathyroid hormone-related peptide. Circulation 98: 1302-1306.

23. Zebger-Gong H, Müller D, Diercke M, Haffner D, Hocher B, et al. (2011) 1,25-Dihydroxyvitamin D3-induced aortic calcifications in experimental uremia: up-regulation of osteoblast markers, calcium-transporting proteins and osterix. J Hypertens 29: 339-348.

24. Liu X, Luo F, Pan K, Wu W, Chen H (2007) High glucose upregulates connective tissue growth factor expression in human vascular smooth muscle cells. BMC Cell Biol 8: 1

25. Somjen D, Paller CJ, Gayer B, Kohen F, Knoll E, et al. (2004) High glucose blocks the effects of estradiol on human vascular cell growth: differential interaction with estradiol and raloxifene. J Steroid Biochem Mol Biol 88: 101 110.

26. Somjen D, Kohen F, Jaffe A, Amir-Zaltsman Y, Knoll E, et al. (1998) Effects of gonadal steroids and their antagonists on DNA synthesis in human vascular cells. Hypertension 32: 39-45.

27. Rashid G, Benchetrit S, Fishman D, Bernheim J (2004) Effect of advanced glycation end-products on gene expression and synthesis of TNF-alpha and endothelial nitric oxide synthase by endothelial cells. Kidney Int 66: 1099-1106.

28. Talmor Y, Golan E, Benchetrit S, Bernheim J, Klein O, et al. (2008) Calcitrio blunts the deleterious impact of advanced glycation end products on endothelial cells. Am J Physiol Renal Physiol 294: F1059-F1064.

29. Schaeffer G, Levak-Frank S, Spitaler MM, Fleischhacker E, Esenabhalu VE et al. (2003) Intercellular signalling within vascular cells under high D-glucose involves free radical-triggered tyrosine kinase activation. Diabetologia 46: 773 483.

30. Suzuki M, Akimoto K, Hattori Y (2002) Glucose upregulates plasminogen activator inhibitor-1 gene expression in vascular smooth muscle cells. Life Sci 72: $59-66$.

31. Sattler AM, Schoppet M, Schaefer JR, Hofbauer LC (2004) Novel aspects on RANK ligand and osteoprotegerin in osteoporosis and vascular disease. Calcif Tissue Int 74: 103-106.

32. Schoppet M, Preissner KT, Hofbauer LC (2002) RANK ligand and osteoprotegerin: paracrine regulators of bone metabolism and vascular function. Arterioscler Thromb Vasc Biol 22: 549-553.
33. Breuil V, Schmid-Antomarchi H, Schmid-Alliana A, Rezzonico R, Euller-Ziegle L, et al. (2003) The receptor activator of nuclear factor (NF)-kappaB ligand (RANKL) is a new chemotactic factor for human monocytes. FASEB $\mathrm{J} 17$ $1751-1753$.

34. Tseng W, Graham LS, Geng Y, Reddy A, Lu J, et al. (2010) PKA-induced receptor activator of NF-kappaB ligand (RANKL) expression in vascular cells mediates osteoclastogenesis but not matrix calcification. J Biol Chem 285 29925-29931.

35. Ndip A, Williams A, Jude EB, Serracino-Inglott F, Richardson S, et al. (2011) The RANKL/RANK/OPG signaling pathway mediates medial arterial calcification in diabetic Charcot neuroarthropathy. Diabetes 60: 2187-2196.

36. Dang DT, Pevsner J, Yang VW (2000) The biology of the mammalian Krüppellike family of transcription factors. Int J Biochem Cell Biol 32: 1103-1121.

37. Pearson R, Fleetwood J, Eaton S, Crossley M, Bao S (2008) Kruppel-like transcription factors: a functional family. Int J Biochem Cell Biol 40: 1996-2001.

38. Autieri MV (2008) Kruppel-like factor 4: transcriptional regulator of proliferation or inflammation, or differentiation, or all three? Circ Res 102: 1455-1457.

39. Feinberg MW, Cao Z, Wara AK, Lebedeva MA, Senbanerjee S, et al. (2005) Kruppel-like factor 4 is a mediator of proinflammatory signaling in macrophages. J Biol Chem 280: 38247-38258.

40. Hamik A, Lin Z, Kumar A, Balcells M, Sinha S, et al. (2007) Kruppel-like factor 4 regulates endothelial inflammation. J Biol Chem 282: 13769-13779.

41. Li HX, Han M, Bernier M, Zheng B, Sun SG, et al. (2010) Krüppel-like factor 4 promotes differentiation by transforming growth factor-beta receptor-mediated Smad and p38 MAPK signaling in vascular smooth muscle cells. J Biol Chem 285: $17846-17856$.

42. Yoshida T, Kaestner KH, Owens GK (2008) Conditional deletion of Krüppel-like factor 4 delays downregulation of smooth muscle cell differentiation markers but accelerates neointimal formation following vascular injury. Circ Res 102 1548-1557.

43. Shalev A, Pise-Masison CA, Radonovich M, Hoffmann SC, Hirshberg (2002) Oligonucleotide microarray analysis of intact human pancreatic islets: identification of glucose-responsive genes and a highly regulated TGFbeta signaling pathway. Endocrinology 143: 3695-3698.

44. Fang $S$, Jin $Y$, Zheng $H$, Yan J, Cui $Y$, et al. (2011) High glucose condition upregulated TXNIP expression level in rat mesangial cells through ROS/MEK MAPK pathway. Mol Cell Biochem 347: 175-182. 